\title{
'Making' labour in Mexican Artisanal workshops
}

Article

Accepted Version

Cant, A. (2018) 'Making' labour in Mexican Artisanal workshops. Journal of the Royal Anthropological Institute, 24 (S1). pp. 61-74. ISSN 1359-0987 doi:

https://doi.org/10.1111/1467-9655.12799 Available at https://centaur.reading.ac.uk/86151/

It is advisable to refer to the publisher's version if you intend to cite from the work. See Guidance on citing.

To link to this article DOI: http://dx.doi.org/10.1111/1467-9655.12799

Publisher: Wiley

All outputs in CentAUR are protected by Intellectual Property Rights law, including copyright law. Copyright and IPR is retained by the creators or other copyright holders. Terms and conditions for use of this material are defined in the End User Agreement.

\section{www.reading.ac.uk/centaur}

\section{CentAUR}

Central Archive at the University of Reading

Reading's research outputs online 


\title{
Cant, Alanna 2018. "Making" Hierarchies of Labour in Mexican Artisanal Workshops.' Journal of the Royal Anthropological Institute 24(S1): S61-S74. https://doi.org/10.1111/1467-9655.12799
}

\begin{abstract}
:
The anthropology of art and craft has been reinvigorated by new theoretical approaches to materiality, creativity, and skill. While such research has been connected to larger politicaleconomic processes such as nationalism, identity and consumerism, these approaches have not been wholly brought to bear on questions of labour. Based on ethnographic research in San Martín Tilcajete, a woodcarving village in Oaxaca, Mexico, I show how labour is made in artisanal workshops through the social and material relations that take place within them. I argue that rather than ownership of the means of production, in San Martin relations of labour are generated by the intermingling of the art world's ideology of 'authorship' with the intimate relations of kinship. The art market locates the production of value in the work of those who are recognised as authors, eliding the labour of many of the workers who produce the carvings. Labourers who work for family members struggle to establish themselves independently in this market because of the multiple and socially salient relations of obligation and respect that are central to kinship and because their own creative work becomes subsumed into the general style of the workshop where they are employed.
\end{abstract}


'Through work, people create themselves through their agency and at the same time create others for whom they work, or with whom they share the fruits of their labours.'

- Olivia Harris, What Makes People Work?

In early January, when the cool morning air takes many hours to heat to its height of the day, Amado finally puts down his blade, steps back from his carving block, and admires his handiwork. ${ }^{1}$ Over the last weeks he has transformed a rough copal branch into the sleek, proud form of a coyote perched on its haunches. Running his palm over the wood, Amado takes a moment to check the horizontal balance of the piece, making a small adjustment to the curvature of its muzzle before giving it a cursory sanding. The coyote will be properly sanded later by someone else in the workshop. With a black permanent marker, he writes 'LIBRE' on masking tape on its flank to indicate that it has not been ordered by a client and is free to sell. Placing it on a shelf where, despite Oaxaca's arid climate, it will take many months to dry out, Amado immediately turns his attention to a new piece of wood, checking the schedule to see what kinds of carvings have been ordered by clients this month. Two months later, on a late March afternoon, Alice and Mark Wilson are visiting Mexico from the United States. They want to order a woodcarving and are looking through the unpainted figures on the shelves when they find the coyote. They agree that this is just the kind of carving they would like to have and begin browsing through the sixty or so vinyl picture albums that document the many different combinations of colours and patterns that can be used to produce the distinctive style that has made this particular workshop famous. Selecting a picture of a mountain lion, they tell Perla who is taking their order that they would like this style of painting but with 'earthier colours'; heavier tones of ochre, sage and rust. Perla notes these directions down in a notebook and records an order number, which she duplicates on the Wilsons' credit card receipt and the flank of the coyote. Later that year, in September, as 
the rainy season draws to a close, Citlali reads over Perla's notes on the colour palette requested by the Wilsons. The coyote has recently received a basecoat of light buff-coloured paint from one of the women who do piecework sanding and painting for the workshop in their own homes. Over the next few weeks, Citlali uses her creativity and knowledge of colours, shapes and forms to cover the coyote with the fine, geometric painting that has become the workshop's signature style, choosing colours that both complement and contrast with the earthy tones requested by the Wilsons. Three weeks later, just before it is readied to be shipped to the Wilsons in the United States, Citlali finally applies the workshop's signature to the bottom of the coyote: 'Miguel and Catalina García.'

In recent years, such close descriptions have become an important technique through which anthropologists illustrate and analyse the complex and often collaborative creative processes that take place around craftwork and material culture more generally. This emphasis on 'making' - as opposed to 'production' - has sensitised the anthropology of art and craft to questions of materiality, affect, skill, learning and cognition, through investigative practices that Tim Ingold describes as 'knowing from the inside' (2013:1-15; cf Marchand 2010, Schneider and Wright 2012). The analytical success of this focus on art producers' affective engagements with their materials and work has inspired a renaissance in the anthropology of art and craft; while in the 1990s it could be described as a marginal subfield (Townsend-Gault 1998: 425), in the past ten years multiple volumes, workshops and digital networks dedicated to such questions have reinvigorated the ethnographic study of art, craft and design. ${ }^{2}$ While research on art and craft is frequently contextualized within larger political-economic processes of nationalism, identity, and consumerism, there remain 
unanswered questions about the micro-politics of 'making' that are obscured by the turn away from 'production.'

Making has pushed theories of craft beyond step-by-step descriptions of how materials are converted into valued objects by emphasising the experiential, relational and indeterminate qualities of production (Venkatesan 2010:168; Wood 2008: 142). But as analysis has moved towards concerns for the aesthetic and affective, it has increasingly become dislocated from questions of labour. In particular, we have not fully reconciled these theoretical interests with the problems of how hierarchies of labour are produced through artisanal work practices and how these practices are integral to capital accumulation at local and translocal levels (Herzfeld 2004; Mohsini 2016; Wilkinson-Weber and Ory DeNicola 2016). This is a troublesome oversight, given the abundance of recent ethnographic work on such themes in industrial anthropology, another subfield generally concerned with the fabrication of objects (e.g. de Neve 2005: 82-136; Kesküla 2014; Parry 2013; Prentice 2015; Sanchez 2016: 127-144). Indeed, the anthropology of craft has previously paid close attention to these concerns: earlier studies of artisan communities focused heavily on how the production and marketing of craftwork reproduced or transformed existing relations of class, gender and ethnicity (e.g. Cook 1990; Kondo 1990; Nash 1993; Stephen 1991). While this earlier Marx-inspired research offered important insights into the changing conditions of artisans within contexts of emergent capitalism, observed inequalities were often explained as resulting from unequal control of the means of production. Yet, as Rudi Colloredo-Mansfeld suggests 'too often capital comes up short as an explanation for the specific patterns of economic differentiation amongst artisans... people use words, art, crafted objects and 
consumer goods to construct competition as an economic and moral field and place themselves within it' (2002: 115,117).

In this article, I investigate how capitalism both accommodates and is transformed by the cultural and social formations in which it takes place by considering how two extraeconomic factors - social intimacy and art world ideology - are central to the production of labour hierarchies and capital accumulation in the workshops and communities in which craft objects are made (cf. Morisawa 2015, Ory DeNicola 2005). Based on ethnographic research with artisans in the village of San Martín Tilcajete, Oaxaca, I argue that hierarchical relations of labour do not necessarily result from the differential control of the means of production. Rather, I suggest that labour - both as a practice of work and a category of persons - must be actively 'made' in workshops, alongside the material objects of the woodcarvings. I show that this is achieved through the productive interplay between the art world's ideology of authorship and the intimate relations of kinship in the workplace. By viewing labour as an outcome of 'making,' the contingent and performative nature of labour relations can be tethered to the actualities of history and place. Accounting for both the emergent and the enduring in experiences of labour is important because, as Harvey and Krohn-Hansen argue in the introduction to this volume, labour mediates between the seemingly malleable and overwhelmingly intractable qualities of capitalism in the contemporary world (18).

\section{Oaxacan Woodcarving in San Martín Tilcajete}

Oaxacan woodcarvings, also known as alebrijes, provide a particularly good lens through which to investigate the ways that emergent labour regimes are made in contemporary 
capitalism, since unlike many other forms of craftwork consumed through globalised art markets, the woodcarvings cannot readily be connected to 'traditional' cultural practices. Their recent origins in San Martín Tilcajete are remembered by all but the youngest artisans, and villagers are acutely aware that their production has introduced dramatic changes to their community in a rather short period of time. The carvings were first developed in the 1960s in the village of San Antonio Arrazola on the outskirts of Oaxaca City, and have always been commercially produced for non-local consumption. It was not until the 1970s that Oaxacan woodcarvings began to be made in San Martín, becoming consolidated as an important source of income for many families in the 1990s (Chibnik 2003:19-35). ${ }^{3}$ Of the three main villages in Oaxaca's Central Valleys region where the carvings are made, San Martín is arguably now the most successful, yet only very few families have been able to translate their work into financial stability. Many villagers must supplement their income from woodcarving with other economic activities, such as operating small corner shops, driving colectivo taxis, and working in the tourism and service sectors. While higher end producers are able to dedicate themselves exclusively to woodcarving, only one family, the Garcías, have become truly economically secure through this work. The Garcías' woodcarvings command very high prices in global art markets that place high value upon the aesthetic and technical capacities of the people that produced them. Since they work with the same materials and basic techniques as everyone else, to their neighbours their incredible success seems mysterious and difficult, if not impossible, to replicate (Cant 2016a).

While woodcarving does not provide economic security for most Tileños (residents of San Martín), sixty percent of the village's households are involved in their production. ${ }^{4}$ This is not surprising given the lack of alternative opportunities, a consequence of larger 
conditions of economic precarity in the region. The state of Oaxaca is characterised by high levels of poverty: the 2010 national census found that 67 percent of Oaxacans live in either 'moderate' or 'extreme' poverty and a further 24 percent are 'economically vulnerable' (CONEVAL 2012: 11-12). This is compounded by Oaxaca's generally weak economy; although the state represents three percent of the nation's population, it contributes only 1.5 percent to Mexico's gross national product (Waterbury 2007: 8). While the municipality of San Martín Tilcajete is certainly not among the poorest in Oaxaca it is nonetheless characterised by 'moderate poverty', that is to say, a majority of Tileños have 'at least one social disadvantage and do not have enough income to meet their basic needs' (SEDESOL 2013). In this context, economic choices for Tileños are limited, and particularly so for young people. Although earlier generations could depend to some degree on peasant agricultural production, the removal of tariffs on imported maize to Mexico in 2008 has made it almost impossible to support a family on agriculture alone (Cohen 2015: 58-59). ${ }^{5}$ Higher education has also been difficult to translate into salaried work. Some Tileños in their forties with college degrees in engineering and computer science cannot find work in these fields, although a few women who have trained in law, office management and accountancy have had more success in Oaxaca City's government and service sectors. Given these conditions, many young men and women view migration to the United States as the only viable means to economic security. Since the 1940s, adult men have travelled to the United States for temporary or seasonal agricultural work. More recently, local men and women have begun to permanently migrate to California and Chicago, where they work in manufacturing, service and domestic labour, almost always without visas. 
To the young women and men who wish to stay in Oaxaca, woodcarving appears to be one of the few options available that might offer the resources to marry and establish their own households. The decision to begin woodcarving is made easier by the fact that there are few barriers of entry to woodcarving work. A small workshop can be set up in any family home, usually in the open courtyard where other household activities take place. The basic costs of tools and materials are generally low; machetes and knives are common implements in most rural Oaxacan homes, and the necessary wood, insecticides and paint are readily available, costing only a few pesos per figure. As such, it is not ownership of the basic means of production that allows control of the market, since all villagers can access them with ease. The skill required to make the most basic woodcarvings also does not constitute a barrier to entering the work, since there are no formal apprenticeship structures and almost every Tileño has an established artisan in their immediate or extended family who can teach them to carve and paint. In addition, all Tileños, by virtue of being from a recognised craft community, can be officially certified as artisans by the Oaxacan Craft Institute, which provides some marketing, financial and logistical support and offers an air of legitimacy in the eyes of buyers. The ease of entry to the market has meant that many Tileños now see 'commercial' woodcarving production - low priced work intended for tourists and wholesalers - as a commonplace activity that shores up incomes from other work. As a result, the lower end of the has been saturated since the late 1990s (Chibnik 2003: 239-242).

Given these conditions, it might be surprising that 'superstar' artisans like the Garcías have been able to emerge from this market at all, especially considering the decline of Mexico's tourism economy in recent years (cf. Colloredo-Mansfeld 2002). ${ }^{6}$ Miguel and Catalina García's continuing success is due to their unique level of exposure to the North 
American indigenous art market, which has allowed them to carve out a new aesthetic niche within the genre of Oaxacan woodcarving (Cant 2016a). They have also benefitted from ongoing relationships with key individuals in the art world of Oaxacan folk art and craft, which is made up of overlapping networks of actors that connect Oaxacan villages with the state capital, Mexico City and the United States. ${ }^{7}$ In Mexico, official promotion of craftwork takes place through public and semi-public institutions like the Oaxacan Craft Institute, the National Fund for the Development of Craftwork, and museums of popular culture. Private dealers and gallery owners based in Mexico and the United States also work to promote those artisans whose work they carry, while looking for new producers whose work might prove marketable. Less directly, journalists, collectors, tour guides and even tourists participate in the economy of recognition that drives artisanal production in contemporary Oaxaca (Chibnik 2003; Wood 2008). The Garcías have successfully positioned themselves within these networks as both clients and patrons. They cultivate personal relationships with important government officials and dealers of popular art; their close relationship with one American dealer was instrumental to their development in their early years, as he facilitated invitations to exhibitions and sales in the United States, through which they gained exposure to collectors and galleries based there. As their renown has grown, they have increasingly become de facto ambassadors of Oaxacan woodcarving, and often represent Oaxacan artisans in general at Oaxacan and federal state cultural events and photo opportunities. At the same time, they have become patrons to other artisans as they mediate between their powerful connections and the local market of producers and also purchase the work of others to sell in their own galleries. 
At the time of my research, other Tileños were unable to replicate the aesthetic and performative techniques and social connections by which the Garcías made themselves and their work exceedingly desirable. As I will show, this desirability is underpinned by the ideology of 'authorship' that governs the art and craft markets in which Oaxacan woodcarvings circulate. But it is also reinforced by the social and affective ties of kinship that connect the Garcías to their workers, and their workers to one another. In village-based artisanal production, where the frameworks of intellectual property law are ineffective or irrelevant, maintaining authorship largely depends on individuals' informal willingness to respect the recognised artist's rights to his or her own work. In San Martín, bonds of kinship within and between workshops facilitate this recognition, and in so doing produce and reinforce hierarchical relationships between those who are recognised as authors and those who are not. Thus, the intermingling of art world concepts of authorship and local experiences of kinship within workshop spaces produces the particular hierarchies of labour that characterise this kind of household-based artisanal commodity production. It is worth emphasising that however exceptional the Garcías' workshop is, these features are present to some degree in all of San Martín's workshops, because Oaxacan woodcarving as a genre is fundamentally organised through relations of kinship and the recognition of authorship. By focusing on the larger and perhaps more inventive workshop of the Garcías, the details of these processes emerge distinctly, while they might be harder to glimpse ethnographically in the small workshops of their neighbours. ${ }^{8}$

In San Martín Tilcajete, the social and affective effects of personal relations, especially amongst kin, transform the rights, obligations and exemptions that normally exist within relations of employment. To put this another way, while workers in the Garcías' 
workshop are indeed engaged in waged employment, their employer-employee relationship is mediated by their meaningful personal relationships with the Garcías and with one another. These relationships are always more socially meaningful than employment, even while at work. The effect of these relationships in the workplace is that the workshop is never just a place of labour and labour at the Garcías is never just about work. In the next section, I show how the intermingling of the intimacy fostered by kinship and the art market's logics of authorship within the space of the workshop creates particular forms and relations of labour which are bound to San Martín Tilcajete as a cultural and social place, but which are also profoundly shaped by the character of the transnational markets for which they work.

\section{Kinship, Authorship and the Making of Labour}

One afternoon in San Martín, I met with Marco Cabrera, a trained computer technician who worked at a motorcycle dealership on the outskirts of Oaxaca City. Although not an artisan himself, in his spare time Marco often helped the municipal artisan association with their event planning. I wanted to discuss the group's relationship with the various government departments that they depended upon. However, Marco wanted to tell me about his son, whose recent withdrawal from his high school course was causing arguments at home. He explained in his typically dramatic manner that his son "was stuck between a sword, a wall and Catalina [García]'. He might finish his education, which seemed to offer very little opportunity in Oaxaca's stagnant climate; follow his friends to the United States to work sin papeles; or work in one of the few large woodcarving workshops in the village. Given the physical and financial risks involved in crossing the U.S. border to work without a visa, I was surprised to discover that this option could be preferable to employment in a workshop at home, especially since the Garcías were members of Marco's extended family. As our 
conversation developed I realised that for Marco employment by a relative carried the potential for coercion. As he put it, 'once you are in, you cannot get out.'

Most Tileño workshops are centred on a married couple, with the husband and older sons carving the figures, and the husband, wife and older children of both sexes sanding, priming and painting. Profits and expenses from carving and other small businesses are directly integrated into the household economy, and many of the artisans I worked with found it difficult to separate their workshop's finances from those of their family. As sons approach adulthood, some may work to establish themselves as recognised artisans in their own right, although many continue to produce their work in their parents' homes, even if they no longer live there. After marriage, daughters may continue painting, especially if their husbands or inlaws are also artisans. ${ }^{9}$ Other members of the extended family, especially nieces, nephews and godchildren, may be included in family workshops on an informal basis, and are usually paid at piece or daily rates. Since they began making carvings in the 1990s, the Garcías have expanded their workshop from this basic arrangement into a more complex venture, with some employees paid hourly wages and others working on piece rates in their own homes. ${ }^{10}$ As their business expanded, Miguel and Catalina initially hired close family members before exploiting more distant links of kinship. In addition to sentiments of affection and belonging, in rural Oaxaca relations of kin are ideally grounded in performances of cooperation and mutual aid, which in turn generate respeto (respect), an important feature that governs social interactions on a daily basis (Cohen 1999; Hunt 1971; Stephen 2005: 265-267). The Garcías were obligated, in no small way, to allow close family members into their business as they became more successful. As their workshop grew and more distant relatives came to work for them, these relations of respect and obligation expanded to their workers' parents, 
grandparents and siblings. Because of this, the Garcías slowly became important local patrons, giving them an air of authority in the community in addition to their importance in the woodcarvings' art market. ${ }^{11}$ Most of the Garcías' employees are young people, between 15 and 25 years of age, and the workshop also became a space for courtship. As romantic relationships between workers developed into marriages, the connections of kinship within the workshop intensified, further fortifying the relations of obligation and respect between these workers and the Garcías, as these young couples depended on them entirely for their livelihoods.

The familial relations that were nurtured by employment in the workshop were overlain by yet another form of kinship that carries more formalised obligations than those with relatives or in-laws: compadrazgo or ritual co-parenthood. Like elsewhere in Latin America, in San Martín compadrazgo is an extremely potent social relationship that demands reciprocal respect and support between a child's parents and her godparents, who become compadres ('coparents') with one another. The importance of respect between compadres is underscored linguistically: where close friends or relatives may speak in Spanish to one another in the familiar 'tu' register, once they become compadres they must shift to the formal 'usted.' In rural Mexico, compadrazgo is very socially complex, as in addition to the celebration of the Catholic sacraments, including confirmation and marriage, it can also be established at secular events, such as the purchase of school supplies or clothing. Although the relationship established at the baptism of a child is paramount, 'lesser compadres' also expect mutual cooperation (Nutini 1984; Cohen 1999: 93-102; Stephen 2005: 265-267). As compadrazgo establishes an expectation of respect and assistance, it can serve to create or reinforce bonds between unequal parties; for obvious reasons, wealthy or powerful families 
are generally considered desirable compadres. The Garcías have become compadres with many of their employees, and have also reciprocated by asking close employee-relatives to become the godparents of their own two children.

Since San Martín is a small community of only about 1,800 people, the multiple layers of kinship and compadrazgo that have developed in the Garcías' workshop recast the hierarchal relations normally found between employers and employees as intimate relationships that exist within a larger and particularly dense network of social relations (cf. Yanagisako 2002; this volume). Miguel and Catalina may be the employers of Amado, Perla and Citlali but they are also very likely to be their cousins, their parents' or grandparents' compadres, or potentially their own compadres or in-laws in the future. This means that good relations with the Garcías are not just important for their work, but also for themselves and their families in other arenas of social life in San Martín. A breakdown of employment relations would not just mean being fired, it could also strain relations between many families in the community, all of whom live and work in very close proximity to one another. This is what Marco means when he says 'once you are in, you cannot get out': to remove oneself from employment could undermine the fabric of kinship and compadrazgo that bind Tileños tightly to one another. While this intertwining of work and social relationships underpins the hierarchical relations of the workshop, most employees do not view this situation negatively, but rather see it as the natural progression of already-existing intimate relationships between themselves, their families and the Garcías, who have assisted and engaged with one another in accordance with the expectations of local social norms. 
The Garcías' workers, neighbours and clients also view their authority within the workshop as naturally deriving from their presumed relationship to the objects that are produced there - not because they are the owners of the workshop per se, but because they are recognised as the authors of the woodcarvings. Since Oaxacan woodcarving did not emerge organically, so to speak, from established cultural practices, artisans initially did not have concrete expectations about the mores and rationales of commercial artisanal work. However, as greater numbers of Tileños began to produce and sell carvings in the 1990s, they simultaneously adapted their perspectives to the logics and expectations of the art markets into which their work flowed. Markets for craftwork and ethnic art attach meaning and value to objects, people, and forms of production that are characterised as 'traditional' and 'authentic' (Errington 1998; Wood 2008). At the same time, however, they reward individuals who manage to develop a 'name for themselves': in Oaxaca, buyers often seek out already-known artisans whose work has been documented in exhibition catalogues, magazines and books, and artisans require certificates from state-run institutes and competitions in order to secure visas and invitations to show their work abroad (Chibnik 2003: 174-234).

In order to establish their name within this saturated economy of recognition, artisans need to strike a fine balance between these two opposing principles: they must cultivate an individual style or aesthetic which is sufficiently distinct from other artisans' work, while not diverging substantially from the recognised genre or 'tradition'. This tension has generated a large amount of ambiguity amongst artisans about what buyers really want when they purchase Oaxacan woodcarvings, and about the relationship between authorship and ownership, which crystallises into intense concerns about copying and competition (Cant 
2015). In many ways, 'names' within this market work along similar logics to brands; it is not only the object that is desired by collectors and connoisseurs, but the combination of the object and the evidence that distinguishes the work of a particular individual or family from similar work made by others, usually in the form of a signature.

Almost all of the woodcarvings produced in San Martín are at least partially made by people who are not recognized as their authors; in small, family workshops where husbands, wives and children work together, the husband's name almost always serves as the workshop's signature. ${ }^{12}$ Since Oaxacan woodcarvings are generally understood as cultural objects, recognised authors must continually emphasize their personal connection to their work, while obscuring the connections created by the work of others who belong to the same culture and place. Thus, while authorship may be abstractly perceived as an inalienable attachment between objects and their makers, the authorial connection is not a certainty and must be continually reproduced and reasserted (Cant 2016b). These processes are most dramatically visible in large workshops like the Garcías' where only a small proportion of the carvings actually pass through Miguel or Catalina's hands. Their 'house style' of carving was initially developed by Miguel over a period of approximately three years in the early 2000 s as he and Catalina worked to develop their name. Today, Miguel very rarely carves pieces himself, and yet the creative work of authorship is still considered to have been done by him, even when employees produce forms that he has never made himself. Likewise, it is Catalina who is understood to have authored the painting repertoire of the workshop, including the colour combinations and specific patterns and designs, even when the painters produce new designs or motifs. 
It is not just the objects that the workshop produces which are understood as belonging to Miguel and Catalina, but the style itself. Davíd, one of Catalina's relatives who works in their painting workshop, also helps his own parents paint their carvings in the evenings after he has finished work. He explained to me that he would never paint his father's carvings in the style that he worked in at the Garcías', even though they might sell for higher prices. He said that this would not be fair, because it would be like stealing. Citlali, a painter who has worked for the Garcías for over two years, also did not question why they should get credit for her work. On one occasion, when some American tourists were visiting the workshop, a young woman hung back as the group progressed towards the carvers. Although she seemed interested in the details of the piece Citlali was working on, she quietly asked in Spanish whether she ever got to sign your own work, 'or is it always signed by the jefes (bosses)?' Citlali's smile flickered for a moment, and then she answered, 'We are all people of this workshop, and this is the name of the workshop, so that is our signature.'

These examples are not meant to suggest that workers are entirely alienated from the objects that their labour produces: employees' creativity and talents are frequently praised and rewarded by the Garcías, and other Tileños recognise many of the workers as some of the best artisans in the village. However, their authorship is not recognized as such and is never publicised; tourists and collectors are never told which painter or carver has made the work they have chosen, although workers themselves often remember. In this way, the artisans who work for the Garcías are made into employees, as they cannot build a career upon their own work. Since they are never recognised as the authors of the carvings that they make, they do not develop a name for themselves or recognition within 
the Oaxacan art world and market, and subsequently would find it very difficult - at least in the short term - if they left the workshop to make carvings on their own. This situation is compounded by the fact that when workers do contribute their intellectual and creative capacities to the carvings they make, their innovations are subsumed into the general style of the Garcías' workshop, as they are never fully free to abandon the Garcías' house style altogether. Labouring in San Martín's workshops thus differs greatly from the traditional European craft guild structures of apprenticeship in which a trainee works under the watchful eye of the master until such time as he is deemed qualified enough to practice his craft under his own name. Unlike San Martín, hierarchy in such traditional guilds is by definition temporary - once the apprentice earns his title as a journeyman, he is free, even obliged, to use all of his skills and knowledge to make his own name for himself (Carrier 1992: 545-546; cf. Herzfeld 2004: 14-27). In Oaxaca the political consequences of the artworld ideology of authorship intermingle within workshop spaces with the affective relationships of kin and compadrazgo to produce and maintain over time hierarchical relations between owners and workers, who are in reality not apprentices. The durability of these relations is reinforced by the employment of relatives, compadres or godchildren, who are believed to be less likely than non-kin to break the norms of the woodcarvings' art world, which insist that only the recognised author of a style has the right to benefit from its production. This is not only because they would risk a loss of very secure employment within precarious economic conditions, but they would also risk creating social frictions that would have consequences for all other aspects of their lives.

In addition to producing labour as an emergent category of persons, this intermingling of kinship and authorship has important consequences for how performing 
such labour is experienced in San Martín Tilcajete. Kinship and compadrazgo carry heavy social obligations that require kin and compadres to support one another through money, goods and work. While usually reserved for expensive fiesta and sacramental life cycle events, such obligations may be called upon at any time, creating a general condition of interdependence at any given moment. In other such socially dense contexts, wage labour may be viewed as a technology through which people attempt to curtail expectations of entitlement between kin, as the exchange of money for services may sever future claims upon the social relations created by labouring together (Martin, this volume). For Oaxacan artisans, however, wage labour itself is sustained by actors' complex relations of kinship, as they are deliberately built on a form of respect that is considered substantially stronger than simple relations of employment. Relations of respeto between employers and workers are crucial within the Oaxacan woodcarving economy of recognition, as workshop owners like Miguel and Catalina must be able to have confidence that their employees are not going to steal their styles and undermine their own authorship and name. Without this assurance, making woodcarvings would become nearly impossible as they would be unwilling to allow their workers to learn how to produce their particular styles of carving and painting. As it is, the Garcías take what seems the reasonable risk of teaching the workers their detailed and highly valuable aesthetic, expanding the workshop's output. At the same time, this relation of respect means that the Garcías are generally keen to develop the workers' own skills and to delegate basic aesthetic decision-making to them; so long as the authorship remains firmly attached to the Garcías' name, carvers and painters who have a certain level of skill are generally encouraged to experiment with forms and colours that complement the Garcías' general style. As such, employees are not under pressure to 'steal skills' from their employers as workers may be in other cases (Herzfeld 2004: 113-138). 
The tension, of course, is that this seemingly balanced system of kinship and respect underwriting relations of wage labour within workshops is simultaneously undermined by the economy of recognition that has contributed to producing it in the first place. In a difficult economic situation where one of the few ways to get ahead is to establish a name for one's self in Oaxacan woodcarving, the pressure to leave employment to begin developing one's own name may be too great in the longer term. Indeed, in the nine years since my fieldwork began, a number of Tileños have begun producing carvings that approximate, with more or less success, the distinctive style of the Garcías' work. Originally made by a few individuals who were not especially close with the Garcías, the availability of these 'imitations' in the market seems to have rendered aspects of their style up-for-grabs for use in the repertoire of Oaxacan woodcarving more generally; pieces from the original woodcarving community of San Antonio Arrazola can now be found that are clearly inspired by the Garcías' style (cf. Schneider 2006 on appropriation as artistic practice). ${ }^{13} \mathrm{~A}$ few particularly skilled employees of the Garcías have now decided to strike out on their own in order to establish themselves as artisans in their own right. As these individuals cultivated their skills and developed their own aesthetic sensibilities while working in the Garcías' house style, it is not surprising that their independent work would be influenced by their previous work. Some of these former employees have managed to maintain friendly relations with Miguel and Catalina, while others have not; in any case, the ideology of authorship and the competitive economy of recognition has now profoundly transformed the experience of social intimacy in San Martín Tilcajete. 


\section{Conclusion}

In the book Making, Ingold enjoins us to recognise that form is emergent from the intersections of human and non-human processes that act upon materials and the environment. This, he says, will allow us to avoid the conceptual difficulties that arise when we imagine production to be merely the 'projection of cultural form upon raw material supplied by nature' (2013: 44). I have suggested in this paper that labour is likewise processual and emergent from the human and non-human conditions in which it is made, however labour also always emerges from the historical, cultural and political-economic structures in which such making takes place. Applying a strategy of 'close description' as developed by craft anthropologists to processes of labour allows the intricate and mediated conditions of localised labour experiences to emerge ethnographically, and shows that labour itself can be viewed as an outcome of the affective and aesthetic qualities of production.

As artisans in San Martín Tilcajete make Oaxacan woodcarvings with their families, co-workers or employers, they simultaneously make their social relations into labour. This labour may be marked by the payment of a wage, as it is in the case of the Garcías' workshop, or it may be concealed within the household, but in all cases, its character is entirely coloured by the social relations and ideological conditions in which their work takes form and acquires value. Workers' labour for the Garcías is inseparable from other sorts of relationships that they have with their employers and with one other; the potent affective relations of kinship and compadrazgo in San Martín draw Tileños together into tightly textured lives. This multiplicity of connectedness means that working experiences of wage labour are also emotional experiences of kinship; employing kin infuses the employer- 
employee relation with all kinds of other rights and obligations. As respect is required amongst kin and compadres, so respect is expected amongst kin and compadres who work together. It is not particularly rare to find that people employ their family members, especially in places where economic security may be hard to come by. However, in the Oaxacan woodcarving workshops of San Martín Tilcajete, the employment of kin alone cannot explain the character of the labour that takes place there. It is also necessary to account for the ways that these artisans understand their work and the objects that they make in order to understand why labour looks the way that it does. The schema of authorship that structures the art world and art markets for Oaxacan craft and ethnic art significantly impacts the ways that labour is both envisioned and enacted by artisans, and so, must be understood as intrinsically part of their labour itself. By considering the emergent affective and aesthetic dimensions of people's work within their larger social lives, we can more satisfactorily account for both the material and social conditions under which inequalities of work are produced, and more broadly the multitude of ways that contemporary capitalism both accommodates and transforms the cultures and societies in which it unfolds (Harvey and Krohn-Hansen, this volume). Labour must remain a central concern for anthropologists addressing these issues, as it allows us to analytically connect the systemic and apparently imperative character of global capitalism with the specific histories of capital relations and the diverse personal experiences of those who 'make' capitalism itself.

\section{Acknowledgements}

The research for this paper was generously funded by the Emslie Horniman Fund of the Royal Anthropological Institute. I would like to thank Christian Krohn-Hansen, Penny 
Harvey, Ingjerd Hoëm, Keir Martin, Marit Melhuus, Knut Nustad, Andrew Sanchez, Astrid Stensrud, Elisabeth Schober, and all of the participants of the Reconfiguration of Labour workshop held in Oslo in June 2015.

\section{Note on Contributor}

Alanna Cant is a postdoctoral research fellow at the School of Anthropology and

Conservation, University of Kent. She holds a Marie Skłodowska-Curie grant from the European Commission for her current research, which looks at the restoration of Catholic churches in rural Mexico.

\section{References}

Cant, Alanna 2015. The Allure of Art and Intellectual Property: artisans and industrial replicas in Mexican cultural economies. Journal of the Royal Anthropological Institute 21(4): 820-837.

-----. 2016a. The Art of Indigeneity: aesthetics and competition in Mexican economies of culture. Ethnos: Journal of Anthropology 81(1): 152-177

. 2016b. Who Authors Crafts? Producing woodcarvings and authorship in Oaxaca, Mexico. In Critical Craft: Technology, Globalization and Capitalism. Clare WilkinsonWeber and Alicia Ory de Nicola, eds. London: Bloomsbury, pp. 19-34

Carrier, James 1992. Emerging Alienation in Production: A Maussian History. Man (n.s.) 27(3): 539-558.

Chibnik, Michael 2003. Crafting Tradition: The Making and Marketing of Oaxacan Woodcarvings. Austin: University of Texas Press.

Cohen, Jeffrey 1999. Cooperation and Community: Economy and Society in Oaxaca. Austin: University of Texas Press.

2015. Eating Soup without a Spoon: Anthropological Theory and Method in the Real World. Austin: University of Texas Press. 
Colloredo-Mansfeld, Rudi 2002. An Ethnography of Neoliberalism: Understanding Competition in Artisanal Communities. Current Anthropology 43(1): 113-137.

CONEVAL [Consejo Nacional de Evaluación de la Politica de Desarrollo Social] 2012. Informe de Pobreza y Evaluación en el Estado de Oaxaca, 2012. Mexico City: CONEVAL.

Cook, Scott 1990. Female Labor, Commodity Production and Ideology in Mexican PeasantArtisan Households. In Work Without Wages: Domestic Labor and Self-Employment within Capitalism. Jane L. Collins and Martha Gimenez, eds. Albany: State University of New York Press, pp. 89-115.

De Neve, Gert 2005. The Everyday Politics of Labour: Working lives in India's informal economy. Delhi: Social Science Press.

Errington, S. 1998. The Death of Authentic Primitive Art and Other Tales of Progress. Berkeley: University of California Press.

Herzfeld, Michael 2004. The Body Impolitic: Artisans and Artifice in the Global Hierarchy of Value. Chicago, University of Chicago Press.

Howell, Jayne 2009 'Union Struggles in Urban Mexico: Oaxaca City Revisited.' Anthropology News 50(4): 53-54

Hunt, Robert C. 1971. Components of Relationships in the Family: A Mexican Village. In Kinship and Culture. Francis L.K. Hsu, ed. London: Aldine Transaction, pp. 106-157.

Ingold, Tim 2013. Making: Anthropology, Archaeology, Art and Architecture. London: Routledge

Kesküla, Eeva 2014. Disembedding the Company from Kinship: Unethical families and atomized labour in an Estonian mine. Laboratorium 6(2): 58-76.

Kondo, Dorinne 1990. Crafting Selves: Power, gender and discourses of identity in a Japanese workplace. Chicago: University of Chicago Press

Marchand, Trevor (ed). 2010. 'Making Knowledge,' The Journal of the Royal Anthropological Institute Special Issue 16(S1): Siii-S202

Mohsini, Mira 2016. Crafting Muslim Artisans: Agency and exclusion in India's urban crafts communities. In Critical Craft: Technology, Globalization and Capitalism. Clare Wilkinson-Weber and Alicia Ory de Nicola, eds. London: Bloomsbury, pp. 239-258.

Morisawa, Tomohiro 2015. Managing the Unmanageable: Emotional Labour and Creative Hierarchy in the Japanese Animation Industry. Ethnography 16(2): 262-284.

Nash, June (ed). Crafts in the World Market: The Impact of Global Exchange on Middle American Artisans. Albany: State University of New York Press. 
Nutini, Hugo 1984. Ritual Kinship Volume 2, Ideological and Structural Integration of the Compadrazgo System in Rural Tlaxcala. Princeton: Princeton University Press

Ory DeNicola, Alicia 2005. Working Through Tradition: Experiential Learning and Formal Training as Markers of Class and Caste in North Indian Block Printing. Anthropology of Work Review 26(2): 12-16.

Parry, Jonathan 2013. 'Company and Contract Labour in a Central Indian Steel Plant,' Economy and Society 42(3): 348-374.

Prentice, Rebecca 2015. Thiefing a Chance: Factory Work, Illicit Labor, and Neoliberal Subjectivities in Trinidad. Denver: University of Colorado Press

SEDESOL [Secretaría de Desarrollo Social] 2013. Catálogo de Localidades: San Martín Tilcajete. Available at http://www.microrregiones.gob.mx/. Accessed 20/01/2016.

Sanchez, Andrew 2015. Criminal Capital: Violence, Corruption and Class in Industrial India. London: Routledge.

Schneider, Arnd 2006. Appropriation as Practice: Art and identity in Argentina. London: Palgrave Macmillan.

Schneider, Arnd and Christopher Wright 2013. Anthropology and Art Practice. London: Bloomsbury

Stephen, Lynn 1991. Zapotec Women. Austin: University of Texas Press.

Townsend-Gault, Charlotte 1998. At the Margin or the Center? - The Anthropological Study of Art. Reviews in Anthropology 27(4): 425-439.

Venkatesan, Soumhya 2010. Learning to Weave, Weaving to Learn... what? Journal of the Royal Anthropological Institute 16(S1): 158-175

Waterbury, Ron 2007. The Rise and Fracture of the Popular Assembly of the Peoples of Oaxaca. Anthropology News 48(3): 8-10.

Wilkinson-Weber, Clare and Alicia Ory DeNicola 2016. Introduction: Taking Stock of Craft in Anthropology. In Critical Craft: Technology, Globalization, and Capitalism. London: Bloomsbury, pp. 1-16.

Wood, William Warner 2008. Made in Mexico: Zapotec weavers and the global ethnic art market. Indianapolis: University of Indiana Press.

Yanagisako, Sylvia 2002. Producing Culture and Capital: Family firms in Italy. Princeton: Princeton University Press. 


\section{Notes}

${ }^{1}$ All personal names in this article are pseudonyms.
${ }^{2}$ See, for example, the Journal of Material Culture; "Anthropologies of Art [A/A]" http://www.anthropologies-
of-art.net/; Taking Stock: Anthropology, Craft and Artisans in the $21^{\text {st }}$ Century
http://anthro.vancouver.wsu.edu/research/Takingstock/; The Research Network for Design Anthropology
https://kadk.dk/en/research-network-design-anthropology.

${ }^{3}$ See Chibnik 2003 for a detailed history and discussion of how the market for Oaxacan woodcarvings changed throughout the 1990s.

${ }^{4}$ Figure based on a survey conducted March to April 2008.

${ }^{5}$ As per requirements of the North American Free Trade Agreement.

${ }^{6}$ Due to a combination of ongoing economic crises and recessions in the United States and highly-visible media coverage of Mexico's drug-related violence. Increasing tensions between successive state governments and various trade unions and social movements have led to frequent protests and blockades in Oaxaca's capital, creating further difficulties for the tourism industry (Waterbury 2007; Howell 2009).

${ }^{7}$ This art world also extends to some degree to Canada, Europe and Japan, where artisans have also shown their work, but the United States is the most significant market for their work outside of Mexico.

${ }^{8}$ My thanks to Keir Martin for helping me work through this point.

${ }^{9}$ Currently, only the second and third generation of artisans in families are establishing themselves independently of their parents. Where children wish to pursue alternatives, such as migration, education or the seminary, there seems little pressure from parents to remain in woodcarving.

${ }^{10}$ Over the course of my fieldwork, there were 4-5 carvers, 20-25 painters and 2 people working on wood preparation, in addition to 5-8 piece rate workers doing preparation in their own homes. Since the time of my fieldwork, the total number has grown to at least sixty and they are now dispersed between two different workshop sites.

${ }^{11}$ This situation was not without difficulties, as the Garcías' personalised power was believed by many to undermine the traditional power structures of the community's collective governance.

${ }^{12}$ In cases where workshops carry the name of the family (e.g. 'workshop of the Salazar Pérez family'), the two surnames used are always those of the adult man, not his wife or other members of the household who participate in production.

${ }^{13}$ They are not 'forgeries' in the sense that they do not claim to be made by the Garcías yet they are clearly appropriating the Garcías' style. 